\title{
The Implementation of Analytical Hierarchy Process Method for Determining Livestock Alabio Duck Development Strategy in Rawa Hulu Sungai Utara
} Implementasi Metode Analytical Hierarchy Process Untuk Menentukan Strategi Pengembangan Ternak Itik Alabio di Rawa Hulu Sungai Utara

Received:

31 August 2020

Accepted:

28 December 2020

Published:

1 February 2021

\author{
${ }^{1 *}$ Yunandar, ${ }^{2}$ Hefni Effendi, ${ }^{3}$ Widiatmaka, ${ }^{4}$ Yudi Setiawan \\ ${ }^{1}$ Natural Resources and Environment Management, Institut Pertanian Bogor. \\ ${ }^{2}$ Aquatic Resource Management, Institut Pertanian Bogor. \\ ${ }^{3}$ Soil Sciences and Land Resources, Institut Pertanian Bogor. \\ ${ }^{4}$ Forest Resources Conservation and Ecotourism, Institut Pertanian Bogor. \\ ${ }^{1,23,4}$ Bogor, West Java, ${ }^{2}$ Banjarmasin, South Kalimantan, Indonesia, \\ E-mail:1,2yunandar01@ulm.ac.id, ${ }^{3}$ hefni_effendi@yahoo.com, \\ ${ }^{4}$ setiawan.yudi@apps.ipb.ac.id
}

*Corresponding Author

\begin{abstract}
The cultivation of Alabio ducks (Anas Platyrynchos Borneo) so far is still natural and only involves one parameter; furthermore, each location has different characteristics. The hierarchical structure constructed has a ranking of importance as an alternative option for ducks' development in peatland ecosystems. This research aims to formulate a strategy for duck production in the Hulu Sungai Utara Regency. AHP (Analytical Hierarchy Process) method in this study is used to structure the decision-making flow from goals and alternatives and weigh the variables. Data collection was carried out with duck farming experts from academia, farmer groups, and policymakers. This study found that the availability of feed, both sago (0.254) and bran (0.218), is a significant component from an ecological perspective. Distance to market $(0.307)$ and hatchery location $(0.287)$ is an economic variable. The social part consists of distance from the settlement (0.443) and labor availability (0.247). Meanwhile, the availability of feed (0.282), hatchery technology (0.269), and Mina ducks $(0.251)$ are the development strategies for duck cultivation in swamp areas, and economic stimulus $(0.93)$ is the final contributor.
\end{abstract}

Keyword-Livestock Ducks, Decision Support Systems, Analytical Hierarchy Process (AHP), Peatland

Abstrak - Kegiatan budidaya itik Alabio (Anas Platyrynchos Borneo) selama ini masih bersifat natural dan hanya melibatkan salah satu parameter padahal setiap lokasi memiliki perbedaan karakteristik. Struktur hirarki yang dibangun memiliki peringkat kepentingan sebagai pilihan alternatif untuk pengembangan ternak itik di ekosistem rawa. Tujuan penelitian ini untuk merumuskan strategi pengembangan produksi itik di Kabupaten Hulu Sungai Utara. Metode AHP (Analytical Hierarchy Process) dalam penelitian ini digunakan untuk menstrukturkan alur pengambilan keputusan dari tujuan dan alternatif serta pemberian bobot terhadap variabel. Pengumpulan data dilakukan dengan sistem pakar peternakan itik melibatkan akademisi, kelompok pembudidaya dan pengambil kebijakan. Penelitian ini menemukan bahwa ketersediaan pakan baik sagu $(0,254)$ dan dedak $(0,218)$ merupakan komponen utama dari sisi ekologi. Jarak terhadap pasar $(0,307)$ dan lokasi pembenihan $(0,287)$ merupakan variabel ekonomi. Komponen sosial terdiri dari jarak dari pemukiman $(0,443)$ dan ketersediaan tenaga kerja (0,247). Sedangkan ketersediaan pakan $(0,282)$, teknologi pembenihan $(0,269)$ dan mina itik $(0,251)$ merupakan strategi pengembangan budidaya itik di daerah rawa, serta stimulus ekonomi $(0,93)$ adalah kontributor terakhir.

Kata Kunci-Ternak Itik, Sistem Penujang Keputusan, Analytical Hierarchy Process (AHP), Rawa

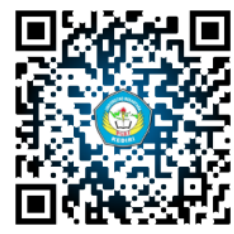

INTENSIF: Jurnal Ilmiah Penelitian dan Penerapan Teknologi Sistem Informasi 
INTENSIF, Vol.5 No.1 February 2021

ISSN: 2580-409X (Print) / 2549-6824 (Online)

DOI: https://doi.org/10.29407/intensif.v5i1.14770

\section{INTRODUCTION}

Alabio ducks (Anas platyrhynchos Borneo) are superior local poultry that produces eggs. Indian runner is a foreign name for Alabio ducks, traditionally known as banner ducks, which initially means original or without mixture. This duck's ability to lay eggs is higher than other birds in one day, laying eggs two times [1][2]. The activity of raising ducks has been carried out for generations. It is the community's central business in the waters of the Hulu Sungai Utara swamp of South Kalimantan. Alabio ducks' activities are currently still subsistence in production quantity, while quality improvement is still less competitive than other poultry. Even though South Kalimantan people highly value this duck's products compared to broilers, especially eggs and commercially, eggs from ducks are known as Tambak eggs and beach ducks. The difference is from the larger size and degree of reddish yolk. Therefore, the demand for products from ducks increases along with people's consumption preferences [3]. The ability of duck production in Indonesia with various maintenance systems is still in the low category due to the unsuitable quality of seeds and feeding [1][2].

The increasing demand for ducks in the market and limited grazing areas due to pressure from settlements, rice fields, and seasons resulted in low feed quality, so that production decreased. Intensive maintenance techniques are applied as a solution for the development of duck farming. However, they are constrained by capital and infrastructure access to remain economically unfeasible and at a loss. Research related to Alabio ducks so far has focused more on carcass fattening [4], genetics produces MA (Mojosari), Peking and Balagung [5], and only regional commodity approaches [6], but still low and subsistence. The concept of development from upstream to downstream in breeding, eggs, meat, animal feed, livestock population volume, and integrated land area is ideal. However, in its implementation, it is still constrained in determining the priority order and development strategy of Alabio ducks so that it is stagnant. Expert-based approaches are an alternative to disentangle problems and prioritize and reduce intensive systems' high costs, but subsistence business activities are not re-practiced. The multi-criteria decision support system method (MCDM) techniques are an answer in determining which it should optimize components and strategies to produce better products. Multi-criteria decision making is used for the suitability of selecting water bodies for the development of duck farming, based on the biophysical, environmental, and socio-economic factors of rural communities that affect sustainability as consideration for optimization. One of the fundamental prerequisites for any cultivation activity is site selection because it can determine success or failure [7]. Poor site selection can damage the environment, result in stress for ducks, the decline in growth and overall production. The practice that has been going on to select cultivation locations has very 
little to consider a holistic assessment of the natural or artificial environment but is limited to technical, economic, logistical, and socio-political factors. The analytic hierarchy process (AHP) simplifies complex, unstructured, strategic, and dynamic problems. A multi-criteria based approach is a widely used instrument to assess the relative importance of multiple factors through pairwise comparisons [8]. This methodology has been used successfully to analyze egg supply chain selection [9], feed ration [10], vegetable supply chain with the addition of Promethee techniques for planning [11], and suitability of land use [12][13][14].

The research objective was to formulate a strategy for developing local duck farming in the Hulu Sungai Utara area by analyzing the main and supporting criteria required in selecting the location. This decision support system technique can assist decision-makers and duck breeders based on bio-ecological, economic, and social characteristics in choosing the site of duck farming businesses. The resulting decision assistance can minimize the impact of losses and optimize production factors for duck farming by determining priority scales based on criteria and strategies built from hierarchical models and priority ranking. The difference between this study and others is the parameters used for the selection of location criteria and procedures for local ducks that are kept in a swamp ecosystem that is multi-criteria and holistic.

\section{RESEARCH METHOD}

The researchers researched Hulu Sungai Utara Regency, South Kalimantan Province, during the dry season from March 2019 to July 2019, involving expert respondents from academics, practitioners, and decision-makers [15] in the Regency and Province. The explanation regarding the development strategy of Alabio ducks and the determination of the standard size value serves as a condition for location availability. It is seen as a bio-ecological, economic, and social aspect of its participants. It implements the development strategy of Alabio ducks in swampy areas that meet the prerequisites. The answers from each respondent are combined to produce a final assessment for a conclusion. Researchers chose the AHP method because it is rational, scientific, a compilation of expert arguments in presenting theory and base practice as an expert, so it is different from intuitive decision making. How the priority strategies and components are prioritized in Alabio ducks' development can be described by AHP. This method can solve complex problems in a development model that is more flexible and easy to understand. AHP can answer research formulations with a hierarchy, assessment of criteria and alternatives, prioritization (strategy), and consistency. The AHP stages of the research are described as follows.

\section{A. Data collection}


INTENSIF, Vol.5 No.1 February 2021

ISSN: 2580-409X (Print) / 2549-6824 (Online)

DOI: https://doi.org/10.29407/intensif.v5i1.14770

The instrument used is in the form of a questionnaire by determining variables or giving weights from expert considerations. The questionnaire is designed from a research objectivebased question structure by comparing parameters, sub-parameters, and alternatives in pairs with a quantitative scale for each level or level that results in ranking. The main principles of AHP are Decomposition, Comparative Judgment, and Logical Consistency [8]. Simplification of unstructured, interacting, strategic multi-parameters so that there is a ranking scale in the hierarchy of criteria, sub-criteria, and alternatives is a driving factor in duck business development more effective and sustainable. Following are the requirements from several references for determining the priority of the Alabio duck business development in swampy areas.

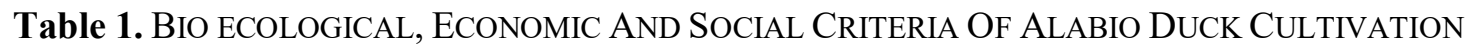

\begin{tabular}{|c|c|c|c|}
\hline \multicolumn{4}{|c|}{ Criteria } \\
\hline Bioecology & Economy & Social & References \\
\hline Distance to sago forest & Distance to market & $\begin{array}{ll}\text { Distance } & \text { from } \\
\text { Residence } & \end{array}$ & $\begin{array}{l}{[16][17][18]} \\
{[19][20]}\end{array}$ \\
\hline Distance to rice fields & Distance from hatchery & Labor & \\
\hline Distance to swampy scrub & Capital institutions & Total population & \\
\hline Distance to inland fish & $\begin{array}{l}\text { Distance to fishing } \\
\text { groups }\end{array}$ & $\begin{array}{l}\text { Directions for the } \\
\text { use of water }\end{array}$ & \\
\hline Typology & & & \\
\hline Rainfall & & & \\
\hline Land use & & & \\
\hline
\end{tabular}

The grouping variables that affect the main priority of activities are a comparative product between all the attributes in the hierarchy of factor levels, objectives, and alternatives in the swamp duck development strategy. Research techniques with AHP have more preferences than the SWOT method [21], Balanced Score[22][23], Simple Additive Weight (SAW) [24], Bayes, Exponential Comparison Method (MPE), and Composite Performance Index (CPI) [25]. The rankings, choices, and variable weights for each hierarchy do not require a unit measurement equation from appropriate planning. The researchers selected the hierarchical structure built from AHP to achieve the Alabio duck development strategy (level 1) based on the hierarchy of expert perceptions. The bio ecological component consists of the variables such as the distance to the potential and source of feed, pasture, periodization of inundation, land use, and rainfall. It is including Economic parameters of space to financial access, seed production, capital, and a group of feed providers. Meanwhile, the proximity of settlements, labor, population, and spatial use plans as social components, all of which are the 2 nd and 3rd levels, respectively. Finally, an analysis of the logical strategy applied to Alabio duck cultivation in swamp waters (level 4) was 
carried out. The clarity of the hierarchical structure of the development of Alabio duck developments of local duck farming is shown in Figure 1.

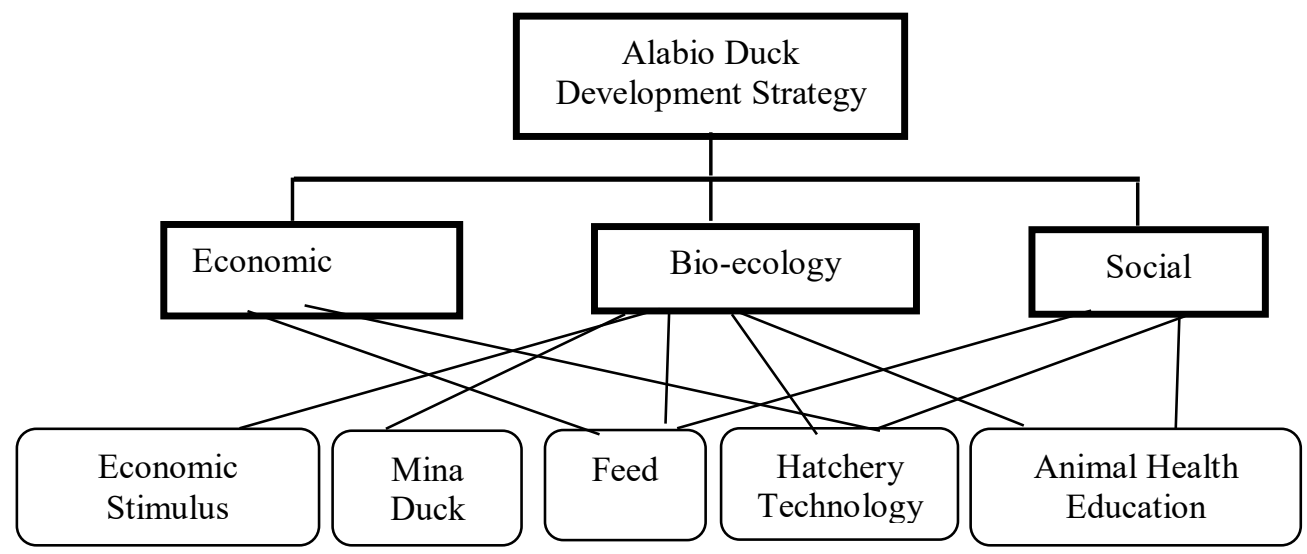

Figure 1. App Structure Of Alabio Duck DeVElopment StRategy

The weigh assessment is according to a list of entries. It should pay attention to the structure that has been made of all categories in pairs with the ordinal series from the choice of numbers 1 to 9 states the weight ratio. Table 2 is a summary of the ranking steps.

Table 2. PAIRED COMPARISON QUALITATIVE INCOME SCALE.

\begin{tabular}{cl}
\hline \hline Value & \multicolumn{1}{c}{ Information } \\
\hline 1 & The two factors are equally important \\
\hline 3 & One factor is slightly more important than the other \\
\hline 5 & One factor is more important than the other \\
\hline 9 & One factor is more important than any other \\
\hline $2,4,6,8$ & Only one factor is more important than any other \\
& $\begin{array}{l}\text { The values between two adjacent equilibrium values } \\
\text { Value of } 2 \text { is when in doubt between } 1 \text { and } 3\end{array}$ \\
& $\begin{array}{l}\text { Value } 4 \text { is when in doubt between } 3 \text { and } 5 \\
\text { A score of } 6 \text { is when in doubt between } 5 \text { and } 7 \\
\text { Value } 8 \text { is when in doubt between } 7 \text { and } 9\end{array}$ \\
The & $\begin{array}{l}\text { If activity i gets one point compared to activity } \mathrm{j} \text { then } \mathrm{j} \text { has the opposite } \\
\text { value compared to i }\end{array}$ \\
\hline
\end{tabular}

B. Data analysis

Several multidisciplinary experts carried out the analysis of the criteria and alternatives in the structure. Still, previously each consistency test was carried out before joining the participant table, using the expert choice tool function.

The following equations are done manually;

$$
\mathrm{X}_{\mathrm{G}}=\sqrt[n]{(\mathrm{X1})(\mathrm{X} 2) \ldots \ldots(\mathrm{Xn})}
$$


INTENSIF, Vol.5 No.1 February 2021

ISSN: 2580-409X (Print) / 2549-6824 (Online)

DOI: https://doi.org/10.29407/intensif.v5i1.14770

In which

$\mathrm{X}_{\mathrm{G}} \quad$ : Geometric mean

$\mathrm{n} \quad$ : Number of expert respondents

$\mathrm{X}_{\mathrm{i}} \quad$ : Assessment by respondent $\mathrm{i}$

The formulation of an expert's answer that does not meet the consistency requirements can be reconfirmed and even annulled for improvement. When the consistency test value is far from perfect, the assessment technique needs to be reviewed, or it needs to be restructured to the basic conceptions that we have built. Consistency Ratio is used as a measure to verify the consistency of expert answers to a series of questions in the pairwise comparative test phase involving the role of RI and CI values.

Table 3. COLLECTION OF RANDOM CONSISTENCY INDICATORS

\begin{tabular}{cccrrrrrrrr}
\hline \hline Rating & $\mathbf{1 , 2}$ & $\mathbf{3}$ & $\mathbf{4}$ & $\mathbf{5}$ & $\mathbf{6}$ & $\mathbf{7}$ & $\mathbf{8}$ & $\mathbf{9}$ & $\mathbf{1 0}$ & $\mathbf{1 1}$ \\
\hline RI & 0,00 & 0,58 & 0,90 & 1,12 & 1,24 & 1,32 & 1,41 & 1,45 & 1,49 & 1,51 \\
\hline
\end{tabular}

The Process Hierarchy Analysis technique's basic concept is a basic multiplication of the mathematical matrix that is processed to determine the eigenvector. The eigenvalues are the squares of the matrix itself, computed values for each row, and normalization. The iteration is fulfilled with the value obtained is less than five decimals.

$$
C I=\frac{\lambda \text { maksimum }-\mathbf{n}}{\mathbf{n}-1}
$$

This study used formulation 2 to evaluate the answers' consistency, which impacted real and large changes in the final results' validation. The standard assessment of the $\mathrm{CI}$ is rated zero (0), indicating a character more significant than $0(\mathrm{CI}>0)$, the applied inconsistency [8][26].

$$
C R=\frac{\mathbf{C I}}{\mathbf{R I}}
$$

The $\mathrm{CR}$ value calculation requires the RI value from the random index from Table 3 released by the Oakridge Laboratory. Inconsistencies, expert respondents' opinion in filling the scale in the pairwise comparison column less than $10 \%$ or 0.1 of the $\mathrm{CR}$ value, can be accommodated. The results of the iteration matrix from paired testing between variables in the hierarchy built are in the form of decimal numbers used as the basis for weighting and ranking/priority determination in future decision-making strategies for duck farm development. What components are the main and need to be implemented to improve and accelerate in the Medium Term Regional Development Plan (RPJMD) and Renstra (Strategic Plan) District. 


\section{Use of the AHP Method}

The Analytic Hierarchy Process's mandatory procedure is Decomposition by describing the problem based on its elements after being defined. This accuracy is carried out to the maximum for the components that make up the hierarchy. The second procedure is called the comparison of the importance of two factors at the same level related to the level above it. Determination of the components that have been analogized through this assessment is the essence of AHP. The product of this activity is displayed in the form of a pairwise comparison matrix. The answer to the problem posed has a priority scale based on the level of importance of the two elements being compared so that the expert understands the case cases being compared to the object of research-assessment on a scale of 1 to 9 , the best score from the expression of expert opinion. The calculation of the relevance of two factors in decision making must have an inverse argument. The formula states $\mathrm{X}$ is preferred $\mathrm{Y}$ with a scale of a, then $\mathrm{Y}$ is selected over $\mathrm{X}$ with a 1 / a scale. The analogy of the number line concept to the right of the number 0 is positive, but in AHP, it is $1 / \mathrm{n}$ and on the left is an integer value that is negative in the number line. Filling in the comparison matrix is only done on the upper triangle because below it is a reflection (a reflection) of the matrix above. Likewise, the ratio between column and row $n(n-1) / 2$ to itself is equal to 1 . Priority synthesis is done by multiplying local preferences by the level above, then adding to each element. This activity's product is a versatile primary choice used to weigh the aspects at the lowest level according to the established criteria. Logical consistency is the last stage of AHP. Collecting all the characteristic vectors from the ranking results in a hierarchical structure to produce is a combined vector ranking in the decision-making-deviations to consistency due to the selected expert's preferences.

\section{RESULT AND DISCUSSION}

The hierarchical structure of the development strategy for duck livestock production, the Hulu Sungai Utara swamp ecosystem, consists of criteria (bioecological, economic, and social), subcriteria (distance to sago forest, distance to rice fields, distance to swamp bushes, distance to inland fish, typology, rainfall)., land use, distance to the market, distance from hatcheries, capital institutions, distance to fishermen groups, distance from habitation, labor, population, and direction of water use and alternatives (feed, hatchery technology, ducklings, livestock health education and economic stimulus).

Based on the results of the AHP analysis of the bioecological components for the Alabio duck farming activities, the main factors that need to be considered are the proximity of the location to food sources, both sago forests with a value of $0.25,0.218$ rice fields, 0.147 swamp bushes, and 
INTENSIF, Vol.5 No.1 February 2021

ISSN: 2580-409X (Print) / 2549-6824 (Online)

DOI: https://doi.org/10.29407/intensif.v5i1.14770

0.147 fisheries activities. Rain and land use with a value of less than 0.12 are supporting factors in developing Alabio ducks in the ecosystem em swamp. Based on this study's findings, the element of feed is the primary determining component of the success of the duck business, which is carried out commercially. Feed errors and shortages adversely affect duck production, reproduction, and mortality. The cost component incurred for feed is the largest. Therefore the proximity of the location to sago forests, rice fields, fishery activities, and swamps, which have variants of aquatic plants, is potential for duck farms to minimize feed costs. Utilization of local feed ingredients in ducks that are kept intensively can increase egg weight at first laying age, body weight, and egg index. [1].

The energy source feed ingredients for Alabio ducks that are currently widely used are bran and sago. Husk becomes waste from the reaction of working rice grains, is not used by the community so that its use is non-competitive, and sago is a food product that can be used as a source of hydrate for charcoal. Generally, it is still consumed as a staple food or other snacks. The protein component is obtained from trash fish, often available in fishermen's premises used by duck farmers, feed on aquatic plants and swamp snails, all of which increase duck production, eggs, and meat. [27]. Furthermore, the results of the AHP analysis of the economic component for Alabio duck farming activities. The main factors that need to be considered are the distance to the market 0.307 and the distance to the hatchery location of 0.287 and the capital institution 0.282. Livestock marketing activities are the essential downstream activities for distributing [28] ducks from breeders to users either directly or through other supply chain mechanisms. An efficient marketing mechanism when products from producers to consumers are economically costly and can manage the distribution evenly of the benefits that are exchanged by final customers across all groups that participate in manufacturing and supply chain flow[29][30][31].

Through this approach, the process of proximity from production to the market and hatcheries is a priority in the development of duck farming in swamps, which can save the transport component. The social element of concern in the development of Alabio ducks in the Hulu Sungai Utara region is that the settlement's location distance has priority 1 with a value of 0.443 . The availability of labor is 0.247 . The components of population and direction of water space use are not so important because their respective values are below 0,2 . The location distance factor to the duck development strategy settlement is the main component of the subsistence management pattern and the vast potential of swamps for livestock activities. This condition is in line with the limited workforce, mainly used from the closest relatives, namely the father, who is very active in caring for laying duck pets. [31]. The expert's calculation and data collection mean geometric are carried out at the weighting stage with pairwise comparisons between the criteria, after entering the questionnaire results for each expert respondent who was compiled to continue 
INTENSIF, Vol.5 No.1 February 2021

ISSN: 2580-409X (Print) / 2549-6824 (Online)

DOI: https://doi.org/10.29407/intensif.v5i1.14770

the AHP calculation with expert choice v11 using equation (1). The following figure describes how the experts assessed, so that table 4 is obtained for the bioecological components.

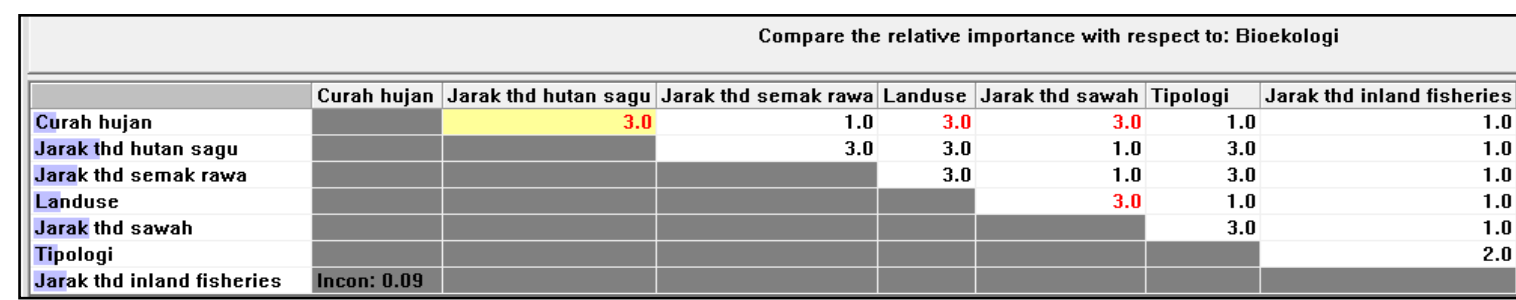

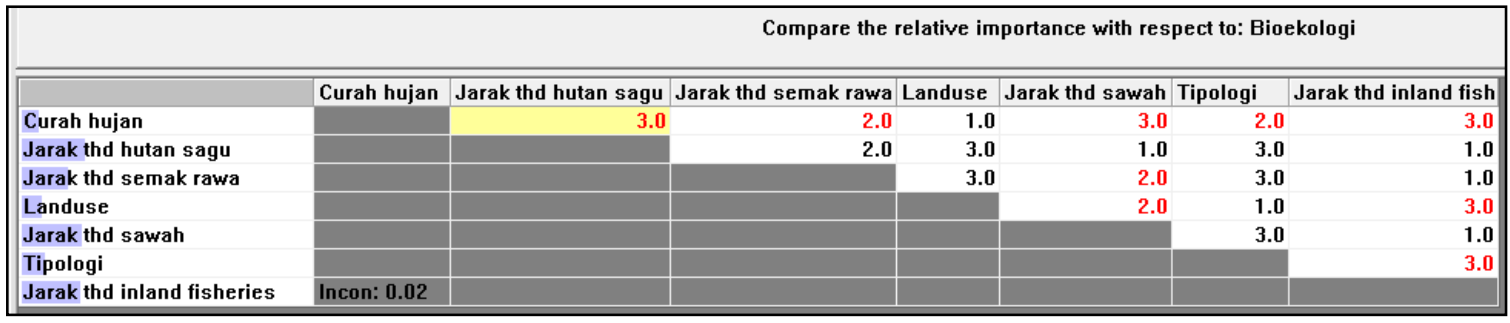

Figure 2. CALCULATION OF RESPONDENTS OF EXPERT RESPONDENTS

The pairwise comparisons consistency test by looking at the Inconsistency/Consistency Ratio with a degree of error of $10 \%$ or a CR value $\leq 0.1$ means the data is in a suitable category. Table 4 shows that the value of $\mathrm{CR}=0.02$ for the bio-ecological component, 0.03 for the economy, and 0.00 for social for the combination of all respondents with a $\mathrm{CR}$ value $\leq$ of 0.1 , the data is consistent.

Table 4. Multiple Comparison Of Alabio Duck Farming Business DeVElopment From GEOMETRIC MEAN EXPERT

\begin{tabular}{|c|c|c|c|c|c|c|c|c|c|c|}
\hline $\begin{array}{l}\text { Bio- } \\
\text { ecological } \\
\text { Components }\end{array}$ & Rainfall & $\begin{array}{l}\text { Distance to } \\
\text { sago forest }\end{array}$ & $\begin{array}{l}\text { Distance } \\
\text { swampy } \\
\text { scrub }\end{array}$ & to & $\begin{array}{l}\text { Land } \\
\text { use }\end{array}$ & $\begin{array}{l}\text { Distance to } \\
\text { rice fields }\end{array}$ & Typology & $\begin{array}{l}\text { Distance to } \\
\text { inland fish }\end{array}$ & Weight & Rank \\
\hline Rainfall & 1 & $1 / 3$ & $5 / 4$ & & $8 / 7$ & $1 / 3$ & $3 / 2$ & $7 / 5$ & 0,069 & 7 \\
\hline $\begin{array}{l}\text { Distance to } \\
\text { sago forest }\end{array}$ & $1 / 3$ & 1 & $5 / 2$ & & 3 & 1 & $5 / 2$ & $7 / 5$ & 0,253 & 1 \\
\hline $\begin{array}{l}\text { Distance to } \\
\text { swampy } \\
\text { scrub }\end{array}$ & $5 / 4$ & $5 / 2$ & 1 & & $5 / 2$ & $9 / 5$ & 2 & $7 / 5$ & 0,152 & 3 \\
\hline Landuse & $8 / 7$ & 3 & $5 / 2$ & & 1 & $5 / 2$ & $7 / 5$ & $7 / 5$ & 0,077 & 6 \\
\hline $\begin{array}{l}\text { Distance to } \\
\text { rice fields }\end{array}$ & $1 / 3$ & 1 & 1 & & $5 / 2$ & 1 & 2 & $7 / 5$ & 0,226 & 2 \\
\hline Typology & $3 / 2$ & $5 / 2$ & 2 & & $7 / 5$ & 2 & 1 & $5 / 4$ & 0,102 & 5 \\
\hline $\begin{array}{l}\text { Distance to } \\
\text { inland } \\
\text { fisheries }\end{array}$ & $7 / 5$ & $7 / 5$ & $7 / 5$ & & $7 / 5$ & $7 / 5$ & $5 / 4$ & 1 & 0,120 & 4 \\
\hline
\end{tabular}


INTENSIF, Vol.5 No.1 February 2021

ISSN: 2580-409X (Print) / 2549-6824 (Online)

DOI: https://doi.org/10.29407/intensif.v5i1.14770

Table 4. Multiple COMParison OF Alabio Duck Farming Business DeVelopMent From GEOMETRIC MEAN EXPERT [CONTINUE]

\begin{tabular}{|c|c|c|c|c|c|c|}
\hline $\begin{array}{l}\text { Economic } \\
\text { Component }\end{array}$ & $\begin{array}{c}\text { Distance to } \\
\text { market }\end{array}$ & $\begin{array}{c}\text { Distance to } \\
\text { duck } \\
\text { hatchery }\end{array}$ & $\begin{array}{c}\text { Capital } \\
\text { institutions }\end{array}$ & $\begin{array}{c}\text { Distance to } \\
\text { farmer } \\
\text { groups }\end{array}$ & Weight & Rank \\
\hline $\begin{array}{l}\text { Distance to } \\
\text { market }\end{array}$ & 1 & 1 & $5 / 4$ & $7 / 2$ & 0,311 & 1 \\
\hline $\begin{array}{l}\text { Distance to } \\
\text { duck } \\
\text { hatchery }\end{array}$ & 1 & 1 & $5 / 4$ & $9 / 5$ & 0,309 & 2 \\
\hline $\begin{array}{l}\text { Capital } \\
\text { institutions }\end{array}$ & $5 / 4$ & $5 / 4$ & 1 & 2 & 0,269 & 3 \\
\hline $\begin{array}{l}\text { Distance to } \\
\text { farmer } \\
\text { groups }\end{array}$ & $7 / 2$ & $9 / 5$ & 2 & 1 & 0,110 & 4 \\
\hline \multicolumn{7}{|c|}{ Consistency ratio (CR) 0,03} \\
\hline $\begin{array}{l}\text { Social } \\
\text { Component }\end{array}$ & $\begin{array}{c}\text { Distance } \\
\text { from } \\
\text { settlement }\end{array}$ & $\begin{array}{c}\text { Total } \\
\text { population }\end{array}$ & $\begin{array}{c}\text { Availability } \\
\text { of labor }\end{array}$ & $\begin{array}{l}\text { Directions } \\
\text { for the use } \\
\text { of water }\end{array}$ & Weight & Rank \\
\hline $\begin{array}{l}\text { Distance } \\
\text { from } \\
\text { settlement }\end{array}$ & 1 & $5 / 2$ & $9 / 5$ & 3 & 0,432 & 1 \\
\hline $\begin{array}{l}\text { Total } \\
\text { population }\end{array}$ & $5 / 2$ & 1 & $7 / 5$ & $5 / 4$ & 0,179 & 3 \\
\hline $\begin{array}{l}\text { Availability } \\
\text { of labor }\end{array}$ & $9 / 5$ & $7 / 5$ & 1 & $9 / 5$ & 0,250 & 2 \\
\hline $\begin{array}{l}\text { Directions } \\
\text { for the use } \\
\text { of water }\end{array}$ & 3 & $5 / 4$ & $9 / 5$ & 1 & 0,139 & 4 \\
\hline
\end{tabular}

The value of the Consistency ratio (CR) analysis from the summary table 4 informs that It can recognize the ranking in the bio-ecological, economic, and social components considering the level of consistency is lower than $0.1(10 \%)$. It can accept the ratio scale if it has stability $(\mathrm{CR}) \leq$ $0.1[8]$, the comparison in this study is 0.02 for the bio ecological component, 0.03 for the economic, detail and 0.00 for the social, element which states that multiple proportions are appropriate and this study is valid. The parts that need to be considered for the development of the Alabio duck farming business in terms of bio ecology are food sufficiency, economic factors, the problem of easy distance/access to markets and hatcheries as well as from the social side that is considered in the form of distance from settlements to facilitate supervision and availability of labor.

The compilation of bioecological, economic, and social components creates alternative strategies based on priorities that must be implemented for swamp duck farming. The top 3 priorities are generated with a value of $>0.2$ or $20 \%$. Based on the results of the sensitivity analysis, researchers found that the bioecological component was a priority with a value of $51.6 \%$ that needed to be considered in the development of Alabio ducks and line with the choice 
INTENSIF, Vol.5 No.1 February 2021

ISSN: 2580-409X (Print) / 2549-6824 (Online)

DOI: https://doi.org/10.29407/intensif.v5i1.14770

of strategies in the form of feed availability, hatchery technology and a combination of maintenance with ducklings. This display is in illustration 3.

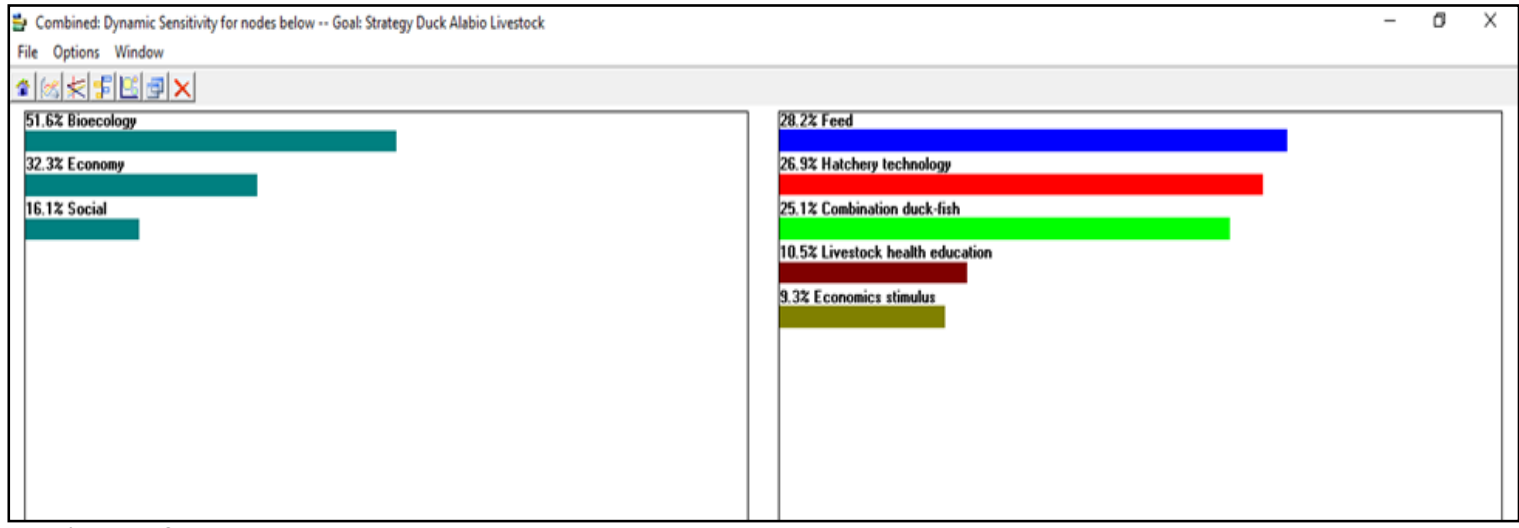

Figure 3. DYNAMIC SENSITIVITY STRATEGY FOR ALABIO DUCK LIVESTOCK DEVELOPMENT

Data processing results with expert choice v11.0 software showed that the feed position has a significant preference and is recommended compared to hatchery technology and ducklings. The feed has a scale of 0.282 , followed by hatchery technology of 0.269 , and is covered by ducklings with a value of 0.251 . From these results, researchers can state that the availability of feed is in a superior position. When a government project implements hatchery technology procurement, the meal must be available by utilizing existing natural resources or by supplying and manufactured feedstock. This component incurs high costs. The alternative of mina ducks can be taken as a balance between the limited feed and the availability of duck seeds that are kept because breeders can pay attention to the grazing environment's carrying capacity, feed, and cages-priority strategy for the development of the Alabio duck business.

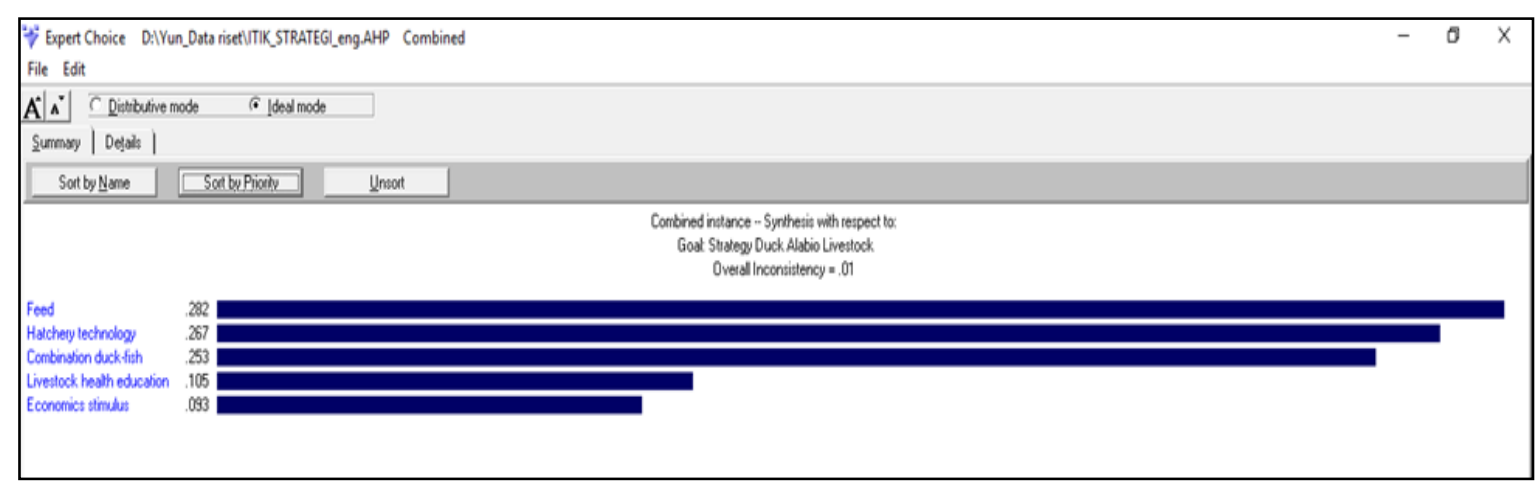

Figure 4. ALternAtive Priorities For ALABIO DUCK LIVESTOCK DEVELOPMENT STRATEGY

This study can accept the results of the analysis of each alternative strategy in livestock development (Figure 4) scientifically because the value is less than $10 \%$ in an overall inconsistency of 0.01 . Strengthening the availability of feed for breeders will provide clarity in the sustainability of future development efforts. The implementation of assistance for livestock businesses that involves interaction with other sectors must be aligned. The implemented 
INTENSIF, Vol.5 No.1 February 2021

ISSN: 2580-409X (Print) / 2549-6824 (Online)

DOI: https://doi.org/10.29407/intensif.v5i1.14770

programs do not overlap, double funding by harmonizing regulations and policies agreed to follow the planning document. It can integrate the stability of the availability of feed with agricultural activities, fisheries, and rejuvenation of sago vegetation, which have been considered common-pool resources. The level of damage is high and costs for purchases outside the region. This condition contributes to the increase in the price of maintaining the duck business.

The integration between the environment, resources, and cultivated products are essential to minimize production costs and increase profit margins from duck farming. The organization's role as a formal and informal institution for rural communities, for guidance in regulating the daily activities of all community members to achieve the chosen targets [32]. The duck livestock policy's technique is institutional management under the North River Hulu Sungai Livestock Service in this condition. The institution's authority is currently still sectoral, where there are other parties' interests, such as the Peat Restoration Agency (BRG), in managing swamp ecosystems. Alabio duck feed's existence involves the availability of raw materials in nature, especially the supply of protein, carbohydrates, and vitamins to improve egg quality. The community and local government's role through related technical offices to preserve and repair and protect germplasm so that it can minimize feed costs and profit margins increase. Selfsufficiency in feed is the primary choice in this strategy. So the government, together with community groups and investors, can make efforts to plant sago/thatch, rice, and fish cultivation and maintain supply chains within the district and export feed needs outside the region; even the position of this area is very strategic. Central and East Kalimantan Provinces.

The sensitivity analysis in this study includes performance sensitivity analysis and dynamic sensitivity analysis. The rendering shows alternatives related to all objectives and overall standards. Modifying the criteria in determining the decision can change the determination of alternative options to display the performance graph indicators' sensitivity analysis tool. Updating one social variable can change the overall priority so that the value of hatchery technology has the highest priority overfeed. The graph in Figure 5 presents three criteria: Bioecology, Economic, and Social, which are the standards for decision-making from the lowest to the highest. The lowest priority for this research activity is feed, hatchery technology, ducks, livestock health, and economic stimulus. Performance sensitivity (Figure 5) informs that economic and social criteria are prioritized for alternative hatchery technology, while the bioecological component is feed. This hatchery technology is prone to experiencing dynamics when there is a shock of changes to each criterion's sub-criteria parameters. The recommended order of decisions for feed, hatchery technology, and ducklings, hatchery technology could be developed by trading-off self-sufficiency in feed or vice versa by considering the vast potential of inundation human resources. 


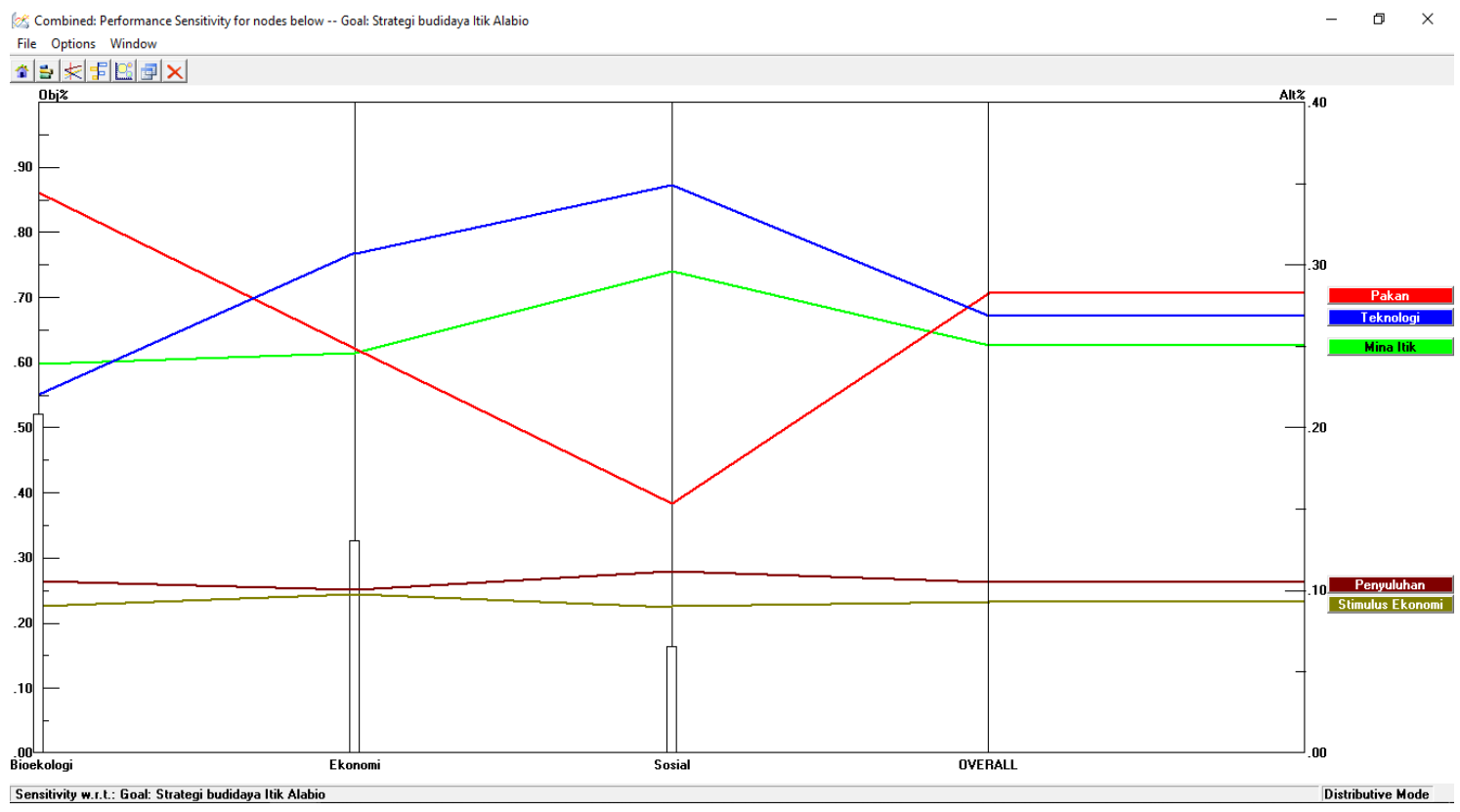

Figure 5. PERFormance SEnSitivity Alabio Duck DeVElopment Strategy

The swamp habitat for the development of Alabio ducks so far still requires a stable feed or feed. It has been inadequate and tends to be deficit due to overexploitation of natural resources, especially sago vegetation, without revegetation efforts to supply dinner from outside the region. This dependence is susceptible to fluctuations in feed prices and the introduction of hatchery technology. It should increase production capacity so that the feed condition must be surplus to expand the market out of the area accompanied by the feed that has been formulated for duck farming so that the criteria and alternative charts can change.

Decision-making systems are often faced with many factors that consider the structure of complexity that is interrelated with one another, unstructured problem-solving techniques that require a dependency on the relationship between its elements. AHP is limited to responding to the interdependence between several components but has not been able to accommodate uncertain and complex problems, cannot be solved using traditional methods, and evaluates issues from the impact of structural changes so that they are more of feedback a hierarchy.

\section{CONCLUSION}

Research using the AHP method provides an advantage in facilitating the formulation of priority strategies for the development of duck livestock production in the Hulu Sungai Utara swamp by preparing feed availability. Therefore, this component's cost can be reduced, then intervened through hatchery technology and feed (integrated rice, fish, and duck). ). The role of 
INTENSIF, Vol.5 No.1 February 2021

ISSN: 2580-409X (Print) / 2549-6824 (Online)

DOI: https://doi.org/10.29407/intensif.v5i1.14770

AHP in decision support activities for the development of Alabio ducks with expert choice resulted in the main recommendations for the priority of natural feed surplus from sago and bran derived from ecological components with cultivation technology. Access and convenience to markets and hatchery locations are economic variables. The distance of the duck farming business from the settlement and labor availability are essential factors of the social component. This priority is the input formulation of the program stages in the District Medium Term Development Plan (RPJMD) based on local potential. Duck development strategy from the AHP method analysis prioritizes the availability of feed (0.282), hatchery technology (0.269), ducklings (0.251), and economic stimulus (0.93). The analysis strategy is built on the comparison between ecological (0.516), financial (0.323), and social (0.161) components. The accuracy test of 0.01 ( $\mathrm{CR} \leq 0.1)$ has confirmed the variables for each element. This strategic priority is recommended in making decisions to develop duck livestock production, both subsistent and modern. Suggestions for this research in the future can be continued with feedback techniques (feedback) without a hierarchy but connected periodically by combining elements of complexity between decision levels so that the next study can apply them for evaluation, forecasting, and mapping.

\section{REFERENCES}

[1] P. R. Matitaputty and H. Bansi, "Upaya Peningkatan Produktivitas Itik Petelur Secara Intensif dan Pemberian Pakan Berbahan Lokal di Maluku," J. Peternak. Sriwij., 2019, doi: $10.33230 /$ jps.7.2.2018.7467.

[2] R. R. Suryana, P. S. Hardjosworo, and L. H. Prasetyo, "Karakteristik Fenotipe Itik Alabio (Anas platyrhynchos Borneo) di Kalimantan Selatan," Bul. Plasma Nutfah, vol. 17, no. 1, p. 61, 2016, doi: 10.21082/blpn.v17n1.2011.p61-67.

[3] Suryono, "Prospek dan peluang pengembangan itik Alabio di Kalimantan Selatan," J. Litbang Pertan., vol. 26, no. 4, pp. 109-114, 2007.

[4] Suprianto IKE; Siti NW; Sukmawati NMS., "Pengaruh Pemberian Probiotik Effecktive Microorganism-4pada Air Minum terhadap Potongan Karkas Komersial Itik Bali Jantan Umur 8 Minggu," Peternak. Trop. J. Trop. Anim. Sci., vol. 0, pp. 599-611, 2019.

[5] Ahmad Zaky Maulana dan Yudhi Putryanda, "Program Pengembangan Peternakan Itik di Kabupaten Hulu Sungai Utara," J. Kebijak. Pembang., vol. 13, no. 1, pp. 57-65, 2018.

[6] M. Nursan and D. Septiadi, "Penentuan Prioritas Komoditas Unggulan Peternakan di Kabupaten Sumbawa Barat," J. Ilm. Agribisnis J. Agribisnis dan Ilmu Sos. Ekon. Pertan., vol. 5, no. 1, pp. 29-34, 2020.

[7] H. Halide, A. Stigebrandt, M. Rehbein, and A. D. Mckinnon, "Environmental Modelling \& Software Developing a decision support system for sustainable cage aquaculture," Environ. Model. Softw., vol. 24, no. 6, pp. 694-702, 2009, doi: 10.1016/j.envsoft.2008.10.013.

[8] L. G. 2012 Saaty T.L., Vargas, Models, Methods, Concepts and Applications of the Analytic Hierarchy Process, 2nd ed. New York: Springer, 2012.

[9] Q. Farhan and Pertiwi, "Analisis Pemilihan Supplier Telur Tetas Dengan Menggunakan Metode Analytical Hierarchy Process," vol. XVIII, no. 1, pp. 39-46, 2017.

[10] O. N. Widyanti, A. Sukmawati, and S. Dirdjosuparto, "Strategies for the Fulfillment of 
Animal Nutritionist Competency Needs at Feedloters in Indonesia," Bul. Peternak., vol. 43, no. 1, pp. 79-85, 2019, doi: 10.21059/buletinpeternak.v43i1.35969.

[11] N. A. Ambar Harsono, Hendro Prassetyo, "Metode Pemilihan Pemasok Sayuran di Supermarket dengan Metode AHP dan PROMETHEE,” J. Itenas Rekayasa Inst. Teknol. Nas., vol. XIII, no 4, pp. 184-195, 2009.

[12] G. Anggraeni, C. Lin, and S. Azizah, "Using AHP to evaluate the critical factors on management of Indonesian restaurant," J. Ilmu-Ilmu Peternak., vol. 29, no. 2, pp. 167177, 2019, doi: 10.21776/ub.jiip.2019.029.02.08.

[13] A. P. Widyassari and T. Yuwono, "Sistem Pendukung Keputusan Pemilihan Rumah di Kawasan Cepu Menggunakan Analytical Hierarchy Process," INTENSIF, vol. 3, no. 1, pp. 10-21, 2019, [Online]. Available: http://ojs.unpkediri.ac.id/index.php/intensif.

[14] R. Anjasmaya and S. Andayani, "Sistem Pendukung Keputusan Penentuan Komoditi Sayuran Berdasarkan Karakteristik Lahan Menggunakan Metode PROMETHEE ( Decision Support System of Vegetable Commodity Selection Based on Land Characteristics Using PROMETHEE Method )," JUITA, vol. VI, no. November, pp. 127-135, 2018.

[15] S. . Hora, "Expert Judgment in Risk Analysis," CREATE, 2010. [Online]. Available: http://research.create.usc.edu/nonpublished_reports/120\%0AThis.

[16] L. H. Prasetyo et al., "Panduan Budidaya Dan Usaha Ternak Itik," CIAWI BOGOR, 2010.

[17] A. S. Bintoro MH, Purwanto HMYJ, Sagu di lahan gambut. Bogor: IPB Press, 2010.

[18] E. Manaroinsong, M. H. Bintoro, D. A. N. D. W. I. Asmono, J. Meranti, and K. I. P. B. Darmaga, "Pengaruh Pemupukan Nitrogen dan Pemangkasan Terhadap Karakter Morfologi Tanaman Sagu (Metroxylon sago Rottb.)," Pengaruh Pemupukan Nitrogen dan Pemangkasan Terhadap Karakter Morfol. Tanam. Sagu (Metroxylon sago Rottb.), vol. 14, no. 2, pp. 109-116, 2016, doi: 10.21082/bp.v14n2.2013.109-116.

[19] J. H. Anderson, J. A. Downs, R. Loraamm, and S. Reader, "Computers, Environment and Urban Systems Agent-based simulation of Muscovy duck movements using observed habitat transition and distance frequencies," CEUS, vol. 61, pp. 49-55, 2017, doi: 10.1016/j.compenvurbsys.2016.09.002.

[20] Krainyk, B. M. Ballard, M. G. Brasher, B. C. Wilson, M. W. Parr, and C. K. Edwards, "Decision support tool: Mottled duck habitat management and conservation in the Western Gulf Coast,” J. Environ. Manage., vol. 230, no. August 2018, pp. 43-52, 2019, doi: 10.1016/j.jenvman.2018.09.054.

[21] Rohmatulloh and S. Winarni, "Evaluasi Prioritas Strategi SWOT dengan Analytical Hierarchy Process," in Prosiding Peranan Statistika di Bidang Pemasaran dalam Penyusunan Strategi Bisnis, 2012, no. October 2012, Vol 3, pp. 1-8, doi: 10.13140/RG.2.1.1628.4565.

[22] Safirin, "Balance Score Card Dan Analytical Hierarchy," Tek. Ind., vol. 11, no. februari, pp. 15-20, 2010.

[23] A. Muhammad, Arif Satria, "Implementasi Strategi Berbasis Balanced Scorecard Untuk Peningkatan Kinerja Kementerian Kelautan dan Perikanan,” J. Ekon. dan Kebijak. Publik, vol. 8, pp. 71-85, 2017.

[24] Diah, S. Dewi, and S. Suryati, "Penerapan Metode AHP dan SAW untuk Penentuan Kenaikan Jabatan Karyawan,” JATISI (Jurnal Tek. Inform. dan Sist. Informasi), vol. 5, no. 1, pp. 60-73, 2018, doi: 10.35957/jatisi.v5i1.130.

[25] A. H. Rangkuti, "Teknik Pengambilan Keputusan Multi Kriteria Menggunakan Metode BAYES, MPE, CPI dan AHP," ComTech Comput. Math. Eng. Appl., vol. 2, no. 1, p. 229, 2011, doi: 10.21512/comtech.v2i1.2738.

[26] T. L. Saaty, "Decision making with the Analytic Hierarchy Process," Int. J. Serv. Sci., vol. 1, no. 1, pp. 215-229, 2008, doi: 10.1504/ijssci.2008.017590.

[27] PIUS P. KETAREN, "Kebutuhan gizi itik petelur dan itik pedaging," WARTAZOA, vol. 12, no. 2, pp. 37-46, 2002. 
INTENSIF, Vol.5 No.1 February 2021

ISSN: 2580-409X (Print) / 2549-6824 (Online)

DOI: https://doi.org/10.29407/intensif.v5i1.14770

[28] S. Darwin Tobaol, SM Rundengan, E K.M Endoh and P. Pangemanan, "Efisiensi Pemasaran Telur Ayam Ras di Kota Manado," ZOOTEC, vol. 38, no. 2, pp. 416-428, 2018.

[29] T. S. dan B. D. S. B. Brata, E. Soetrisno, "Populasi dan Manajemen Pemeliharaan serta Pola Pemasaran Ternak Itik (Studi Kasus di Desa Pematang Balam Kecamatan Hulu Palik Kabupaten Bengkulu Utara)," J. Sain Peternak. Indones., vol. 15, no. 1, pp. 98109, 2020, doi: 10.1017/CBO9781107415324.004.

[30] N. Wahyuni and N. Suryati, "Analisis Kelayakan Finansial Usahatani Terpadu Padi Itik Di Kabupaten Musi Rawas," Soc. J. Ilmu-Ilmu Agribisnis, vol. 7, no. 1, p. 17, 2018, doi: $10.32502 /$ jsct.v7i1.1132.

[31] Erlina, "Keterkaitan Subsistem Agribisnis Itik Alabio Petelur di Kabupaten Hulu Sungai Utara Provinsi Kalimantan Selatan," IJAS, vol. 3, pp. 73-77, 2013.

[32] Anantanyu, "Kelembagaan Petani: Peran dan Strategi Pengembangan Kapasitas," SEPA, vol. 7, no. 2, pp. 102-109, 2011.

120 INTENSIF: Jurnal Ilmiah Penelitian dan Penerapan Teknologi Sistem Informasi 